\title{
Micronucleus Assay in Exfoliated Buccal Epithelial Cells Using Liquid Based Cytology Preparations in Building Construction Workers
}

\author{
Arul $\mathbf{P}^{1 *}$, Shetty Smitha ${ }^{1}$, Suresh Masilamani ${ }^{1}$, Akshatha $\mathbf{C}^{1}$ \\ 1. Dept. of Pathology, Dhanalakshmi Srinivasan Medical College and Hospital, Siruvachur, Perambalur, \\ Tamilnadu-621113, India
}

\begin{tabular}{|c|c|}
\hline KEYWORDS & ABSTRACT \\
\hline $\begin{array}{l}\text { Liquid Based Cytology } \\
\text { Preparations }\end{array}$ & $\begin{array}{l}\text { Background and objective: Cytogenetic damage in exfoliated buccal epithelial } \\
\text { cells due to environmental and occupational exposure is often monitored by } \\
\text { micronucleus (MN) assay using liquid based cytology (LBC) preparations. This }\end{array}$ \\
\hline $\begin{array}{l}\text { Exfoliated Buccal Epithelial } \\
\qquad \text { Cells }\end{array}$ & $\begin{array}{l}\text { study was performed to evaluate MN in exfoliated buccal epithelial cells of building } \\
\text { construction workers using LBC preparations. }\end{array}$ \\
\hline $\begin{array}{l}\text { Micronucleus } \\
\text { Building Construction }\end{array}$ & $\begin{array}{l}\text { Methods: LBC preparations of exfoliated buccal epithelial cells from } 100 \\
\text { subjects [ } 50 \text { building construction workers (cases) and } 50 \text { administrative staffs } \\
\text { (controls)] was evaluated by May-Grunwald Giemsa, Hematoxylin and Eosin and }\end{array}$ \\
\hline \multirow[t]{2}{*}{ Workers } & $\begin{array}{l}\text { Papanicolaou stains. Student's t test was used for statistical analysis and a P value of } \\
<0.05 \text { was considered as statistically significant. }\end{array}$ \\
\hline & $\begin{array}{l}\text { Results: The mean frequencies of } \mathrm{MN} \text { for cases were significantly higher than } \\
\text { controls regardless of staining methods used. There were statistically significant } \\
\text { differences between smokers and non-smokers of the controls as well as duration of } \\
\text { working exposure ( }<5 \text { and }>5 \text { years) and smokers and non-smokers of cases }\end{array}$ \\
\hline Article Info & $(\mathrm{P}=0.001)$. However, there were meaningful differences regarding mean frequencies \\
\hline & $\begin{array}{l}\text { of } \mathrm{MN} \text { between smokers, non-smokers, those with alcohol consumption or not in } \\
\text { cases and controls using various stains }(\mathrm{P}=0.001) \text {. }\end{array}$ \\
\hline Received 05 Jun 2016; & Conclusion: There was an increased risk of cytogenetic damage in building \\
\hline Accepted 26 Apr 2017; & $\begin{array}{l}\text { construction workers. However, evaluation of } \mathrm{MN} \text { of exfoliated buccal epithelial } \\
\text { cells in building construction workers serve as a minimally invasive biomarker for }\end{array}$ \\
\hline Published Online 2017; & $\begin{array}{l}\text { cytogenetic damage. } \mathrm{LBC} \text { preparations can be applied for } \mathrm{MN} \text { assay as it improves } \\
\text { the quality of smears and cell morphology, decreases the confounding factors and } \\
\text { reduces false positive results. }\end{array}$ \\
\hline
\end{tabular}

Corresponding information: Dr.Arul.P, Dept. of Pathology, Dhanalakshmi Srinivasan Medical College and Hospital, Siruvachur, Perambalur, Tamilnadu-621113, India, India, Mobile: +919500474972, Email: drarul3@gmail.com

Copyright @ 2017, IRANIAN JOURNAL OF PATHOLOGY. This is an open-access article distributed under the terms of the Creative Commons Attribution-noncommercial 4.0 International License which permits copy and redistribute the material just in noncommercial usages, provided the original work is properly cited.

\section{Introduction}

Micronucleus $(\mathrm{MN})$ is indicative of either a fragmented or whole chromosomes extruded from the main nucleus during the process of mitosis. These acentric fragments or lost chromosomes gives rise to small nuclei which appear similar to the main nuclei on staining known as $\mathrm{MN}(1,2)$. Therefore, $\mathrm{MN}$ assay is an ideal parameter to serve as a biomarker (3). High frequencies of $\mathrm{MN}$ have been demonstrated in exfoliated buccal cells in those occupationally exposed to toxic environmental agents such as solvents, polycyclic aromatic hydrocarbons, emissions of sugarcane straw burning, gasoline, arsenic and anti-neoplastic drugs compared to the controls (4).

Building construction workers are exposed to numbers of hazardous agents daily and for long period. Most of them are classified as carcinogenic or possibly carcinogenic namely dust, chemicals, asbestos and quartz dust of crystalline silica. Some authors have found that cement and concrete substances may be carcinogenic in nature $(5,6)$. 
Cells of buccal mucosa play role as the first barrier for inhalation or ingestion route and can metabolize carcinogenic agents to reactive chemical substances. They often considered as appropriate site for assessment of early cytogenetic damage as about $90 \%$ of human cancers are epithelial in origin (7).

Liquid based cytology (LBC) was first applied to gynecological cytology almost 25 years ago (8). Since its introduction, many laboratories have started to apply LBC to nongynecological sample and exfoliated buccal epithelial cells (9). LBC can substitute conventional smear; because it provides many advantages namely enhanced slide preparations and decreases the amount of mucus, blood and inflammatory cells. Routinely prepared slides for analysis of MN contains bacteria, staining deposits, nuclear fragments and other cytoplasmic cells and necrotic cores that can be confused with $\mathrm{MN}$, which may lead to false positive results. However, slides prepared using LBC can eliminate or decrease these confounding factors; hence, LBC may serve as a reliable technique for $\mathrm{MN}$ analysis $(7,10-12)$. The present study was undertaken to evaluate the frequencies of MN of exfoliated buccal epithelial cells using LBC preparations in building construction workers.

\section{Materials and Methods}

\section{Overview of study design}

This prospective study was performed in the department of pathology, Dhanalakshmi Srinivasan Medical College and Hospital, Perambalur, Tamilnadu, India from August 2015 to October 2015. An ethical approval was obtained from the Institutional Ethical Committee. An informed written consent was taken from each patient.

\section{Study population}

A total of 100 healthy subjects, 50 building construction workers (cases) and 50 hospital administrative staffs (controls) without any type of oral lesions entered the study. All subjects were asked to complete the questionnaire to obtain demographic data including history of cigarette smoking and alcohol. Betel nut/tobacco chewers were excluded from the investigation.

\section{Collection of specimens, staining and evaluation criteria}

Prior to collection of exfoliated buccal epithelial cells, oral cavity was rinsed with water. Sterile wooden spatula was introduced into the mouth, scraped on the buccal mucosa and the sample placed in preservative solution for minimum of half an hour. Subsequently the sample was centrifuged at $1500 \mathrm{rpm}$ for $5 \mathrm{~min}$. The supernatant was discorded. One drop of normal saline was added to pellet and mixed well to get homogenous sample. Totally $50 \mathrm{uL}$ of diluted pellet was placed on clean slides with a drop of fixative solution and stained with May-Grunwald Giemsa (MGG), Hematoxylin and Eosin (H \& E) and Papanicolaou stain (Pap) using standard staining techniques. The criteria established by Tolbert et al. (13) and El-Setouhy et al. (14) were used to count the frequencies of $\mathrm{MN}$ in 1000 exfoliated buccal epithelial cells from each subject. The slides were examined under light microscope by pathologists. However, binucleate cells or cells with fragmented nuclei, karyolysis and nuclei appearing as broken eggs were not counted as MN.

\section{Statistical analysis}

Student's t test was used to compare the mean frequencies of $\mathrm{MN}$ found in all stains in both cases and controls. $\mathrm{P}<0.05$ was considered as statistically significant. Statistical analysis was performed using International Business Machines (IBM) Corporation Statistical Package for the Social Sciences (SPSS) Statistics for Windows (version 20.0. Armonk, New York: IBM Corporation).

\section{Results}

The mean age of cases and controls were 44.36 and 43.96 years respectively. Among 50 cases, 17 (34\%) were smokers and 21 (42\%) used alcohol. Nineteen (38\%) were smokers and 18 (36\% used alcohol among 50 controls. The mean length of working in building construction of cases was 17.34 years. The number of $\mathrm{MN}$ found in the present study were $854 \mathrm{MN}$ with MGG, 926 with H\&E and 1203 with Pap stain. The mean frequencies of $\mathrm{MN}$ in cases compared to controls stained with MGG (Figure 1A), H \& E (Figure 1B) 
and Pap stain (Figure 1C) were 18.74 vs 9.12, 19.96 vs 10.14 and 27.7 vs 14.84 , respectively.
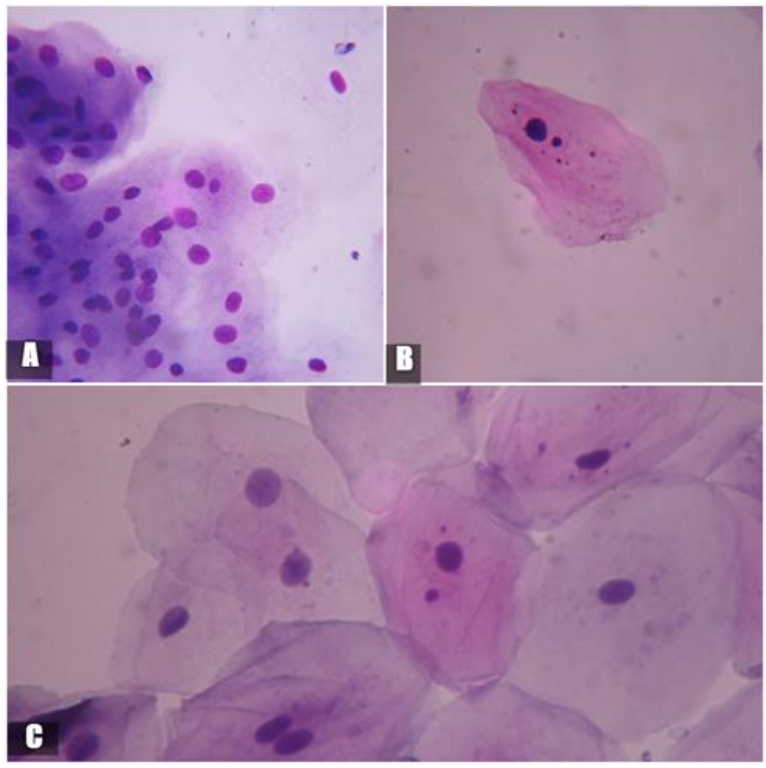

Fig 1. Liquid based cytology preparations showing exfoliated buccal epithelial cells with micronucleus. (A) May-Grunwald Giemsa, x400. (B) Hematoxylin and Eosin, x400. (C) Papanicolaou stain, x400.
These findings were statistically significant $(\mathrm{P}=0.001)$ regardless of staining methods used (Table 1).

Frequencies of $\mathrm{MN}$ by different staining methods did not reveal significant differences regarding age ( $<40$ and $>40$ years) and alcohol consumption in controls and cases. Whereas, the mean frequencies of $\mathrm{MN}$ between smokers and non-smokers of the controls as well as duration of working exposure ( $<5$ and $>5$ years) and smokers and non-smokers of cases reached a significant level $(\mathrm{P}=0.001)$. On intercomparison of mean frequencies of $\mathrm{MN}$ between smokers, nonsmokers, alcoholics and non-alcoholics of cases and controls using various stains showed significant statistical differences $(\mathrm{P}=0.001)$ (Table 2 to Table 4).

Table 1. Comparison of Mean Frequency of MN Using Student's t Test among All Stains

\begin{tabular}{|c|c|c|c|c|c|c|c|c|c|}
\hline \multirow[b]{2}{*}{ Stain } & \multicolumn{4}{|c|}{ Cases } & \multicolumn{4}{|c|}{ Control } & \multirow[b]{2}{*}{$P$-Value } \\
\hline & Number & Mean \pm Sl & edian & $\begin{array}{l}\text { Minimur } \\
\text { maximur } \\
\text { values }\end{array}$ & Number & Mean \pm SD & Median & $\begin{array}{l}\text { Minimum- } \\
\text { maximum value: }\end{array}$ & \\
\hline MGG & 50 & $18.74 \pm 7$ & 18 & $8-47$ & 50 & $9.12 \pm 6$ & 8 & $3-43$ & $<0.001$ \\
\hline H\&E & 50 & $19.96 \pm 6.4 !$ & 19.5 & $9-49$ & 50 & $10.14 \pm 6.2$ & 9.5 & $4-46$ & $<0.001$ \\
\hline Pap & 50 & $27.7 \pm 6.27$ & 26.5 & $17-49$ & 50 & $14.84 \pm 6.31$ & 13 & $8-48$ & $<0.001$ \\
\hline
\end{tabular}

MGG: May-Grunwald Giemsa; H \& E: Hematoxylin and Eosin; Pap: Papanicolaou stain;*P value $<0.05$ was considered as statistically significant

Frequencies of $\mathrm{MN}$ by different staining methods did not reveal significant differences regarding age ( $<40$ and $>40$ years) and alcohol consumption in controls and cases. Whereas, the mean frequencies of MN between smokers and non-smokers of the controls as well as duration of working exposure ( $<5$ and $>5$ years) and smokers and non-smokers of cases reached a significant level $(\mathrm{P}=0.001)$. On intercomparison of mean frequencies of $\mathrm{MN}$ between smokers, nonsmokers, alcoholics and non-alcoholics of cases and controls using various stains showed significant statistical differences $(\mathrm{P}=0.001)$ (Table 2 to Table 4). 
Table 2. Frequency of MN Regarding Age, Smoking and Alcohol Consumption in Controls with Various Stains (N=50)

Stain

MGG
Individuals

$$
\begin{aligned}
& \text { Age (year) } \\
& <40(\mathrm{~N}=24) \\
& >40(\mathrm{~N}=26)
\end{aligned}
$$

Smoking

Yes $(\mathrm{N}=19)$

No $(\mathrm{N}=31)$
MN (Mean \pm SD $)$

$8.32 \pm 3.23$

$8.65 \pm 5.78$
$P$-value

0.001

$$
\begin{gathered}
8.69 \pm 4.82 \\
8.21 \pm 4.3
\end{gathered}
$$

0.72

\section{Age (year)}

$<40(\mathrm{~N}=24)$

$>40(\mathrm{~N}=26)$

$$
\begin{aligned}
& 9.41 \pm 4.25 \\
& 9.81 \pm 4.63
\end{aligned}
$$

$$
9.51 \pm 4.98
$$

$4.69 \pm 4.06$

No $(\mathrm{N}=31)$

Alcohol consumption

Yes $(\mathrm{N}=18)$

No $(\mathrm{N}=32)$

$$
\begin{aligned}
& 9.56 \pm 4.79 \\
& 9.21 \pm 4.12
\end{aligned}
$$

$$
\begin{aligned}
& \text { Age (year) } \\
& <40(\mathrm{~N}=24) \\
& >40(\mathrm{~N}=26)
\end{aligned}
$$

\section{Smoking}

Pap
$12.43 \pm 5.07$

0.86
Yes $(\mathrm{N}=19)$

No $(\mathrm{N}=31)$
$13.79 \pm 5.82$

$8.14 \pm 5.24$
0.001
Alcohol consumption
Yes $(\mathrm{N}=18)$
$13.98 \pm 5.66$
No $(\mathrm{N}=32)$

0.68

MGG: May-Grunwald Giemsa; H \& E: Hematoxylin and Eosin; Pap: Papanicolaou stain; *P value <0.05 was considered statistically significant 
Table 3. Frequency of MN Regarding Age, Smoking, Alcohol Consumption and Years of Working Exposure in Cases with Various Stains $(\mathrm{N}=50)$

\begin{tabular}{|c|c|c|c|}
\hline Stain & Individuals & MN $\quad($ Mean \pm SD $)$ & $P$-value \\
\hline \multirow{4}{*}{ MGG } & $\begin{array}{l}\text { Age }(\text { year }) \\
<40(\mathrm{~N}=20) \\
>40(\mathrm{~N}=30)\end{array}$ & $\begin{array}{l}16.52 \pm 6.12 \\
17.43 \pm 6.87\end{array}$ & 0.62 \\
\hline & $\begin{array}{l}\text { Smoking } \\
\text { Yes }(\mathrm{N}=17) \\
\text { No }(\mathrm{N}=33)\end{array}$ & $\begin{array}{l}17.72 \pm 6.86 \\
11.04 \pm 5.32\end{array}$ & 0.001 \\
\hline & $\begin{array}{l}\text { Alcohol consumption } \\
\begin{array}{l}\text { Yes }(\mathrm{N}=21) \\
\text { No }(\mathrm{N}=29)\end{array}\end{array}$ & $\begin{array}{l}17.12 \pm 6.71 \\
16.88 \pm 5.41\end{array}$ & 0.89 \\
\hline & $\begin{array}{l}\text { Working exposure (year) } \\
\qquad \begin{array}{c}<5(\mathrm{~N}=27) \\
>5(\mathrm{~N}=23)\end{array}\end{array}$ & $\begin{array}{l}12.02 \pm 4.33 \\
17.75 \pm 5.92\end{array}$ & 0.001 \\
\hline \multirow{4}{*}{ H\&E } & $\begin{array}{l}\text { Age }(\text { year }) \\
<40(\mathrm{~N}=20) \\
>40(\mathrm{~N}=30)\end{array}$ & $\begin{array}{l}16.65 \pm 6.11 \\
17.87 \pm 6.93\end{array}$ & 0.51 \\
\hline & $\begin{array}{l}\text { Smoking } \\
\text { Yes }(\mathrm{N}=17) \\
\text { No }(\mathrm{N}=33)\end{array}$ & $\begin{array}{l}18.59 \pm 6.38 \\
11.36 \pm 5.81\end{array}$ & 0.001 \\
\hline & $\begin{array}{l}\text { Alcohol consumption } \\
\qquad \begin{array}{l}\text { Yes }(\mathrm{N}=21) \\
\text { No }(\mathrm{N}=29)\end{array}\end{array}$ & $\begin{array}{l}17.59 \pm 6.44 \\
16.06 \pm 5.79\end{array}$ & 0.39 \\
\hline & $\begin{array}{l}\text { Working exposure (year) } \\
\qquad \begin{array}{c}<(\mathrm{N}=27) \\
>5(\mathrm{~N}=23)\end{array}\end{array}$ & $\begin{array}{l}12.57 \pm 4.27 \\
18.85 \pm 5.87\end{array}$ & 0.001 \\
\hline \multirow{4}{*}{ Pap } & $\begin{array}{l}\text { Age }(\text { year }) \\
<40(\mathrm{~N}=20) \\
>40(\mathrm{~N}=30)\end{array}$ & $\begin{array}{c}24.34 \pm 5.9 \\
25.77 \pm 6.45\end{array}$ & 0.41 \\
\hline & $\begin{array}{l}\text { Smoking } \\
\text { Yes }(\mathrm{N}=17) \\
\text { No }(\mathrm{N}=33)\end{array}$ & $\begin{array}{l}26.17 \pm 6.29 \\
19.77 \pm 5.01\end{array}$ & 0.001 \\
\hline & $\begin{array}{l}\text { Alcohol consumption } \\
\qquad \begin{array}{c}\text { Yes }(\mathrm{N}=21) \\
\text { No }(\mathrm{N}=29)\end{array}\end{array}$ & $\begin{array}{l}24.14 \pm 5.42 \\
23.32 \pm 4.67\end{array}$ & 0.58 \\
\hline & $\begin{array}{l}\text { Working exposure (year) } \\
\qquad 5(\mathrm{~N}=27) \\
>5(\mathrm{~N}=23)\end{array}$ & $\begin{array}{l}20.16 \pm 4.67 \\
26.43 \pm 6.01\end{array}$ & 0.001 \\
\hline
\end{tabular}

MGG: May-Grunwald Giemsa; H \& E: Hematoxylin and Eosin; Pap: Papanicolaou stain; $P$-value $<0.05$ was considered statistically significant 
Table 4. Intercomparison of Frequency of MN between Cases and Controls Using Various Stains

\begin{tabular}{|c|c|c|c|c|c|c|}
\hline \multirow{2}{*}{$\begin{array}{c}\text { Intercomparison of cases and } \\
\text { control }\end{array}$} & \multicolumn{2}{|c|}{ MGG } & \multicolumn{2}{|c|}{ H\&E } & \multicolumn{2}{|c|}{ PAP } \\
\hline & $\begin{array}{c}\text { MN } \\
\text { Mean } \pm \text { SD) }\end{array}$ & $P$-value & $\begin{array}{c}\text { MN } \\
\text { Mean } \pm \text { SD) }\end{array}$ & $P$-value & $\begin{array}{c}\text { MN } \\
\text { Mean } \pm \text { SD) }\end{array}$ & $P$-value \\
\hline Cases smokers (N=17) & $17.72 \pm 6.86$ & & $18.59 \pm 6.38$ & & $26.17 \pm 6.29$ & \\
\hline Control smokers (N=19) & $8.74 \pm 4.43$ & 0.001 & $9.51 \pm 4.98$ & 0.001 & $13.79 \pm 5.82$ & 0.001 \\
\hline Cases non-smokers $(\mathrm{N}=\mathbf{3 3})$ & $11.04 \pm 5.32$ & & $11.36 \pm 5.81$ & & $19.77 \pm 5.01$ & \\
\hline Control non-smokers $(\mathrm{N}=31)$ & $4.55 \pm 4.05$ & 0.001 & $4.69 \pm 4.06$ & 0.001 & $8.14 \pm 5.24$ & 0.001 \\
\hline Cases alcoholics $(\mathrm{N}=21)$ & $17.12 \pm 6.71$ & & $17.59 \pm 6.44$ & & $24.14 \pm 5.42$ & \\
\hline Control alcoholics $(\mathrm{N}=18)$ & $8.69 \pm 4.82$ & 0.001 & $9.56 \pm 4.79$ & 0.001 & $13.98 \pm 5.66$ & 0.001 \\
\hline Cases non-alcoholics (N=29) & $6.88 \pm 5.41$ & & $23.32 \pm 4.67$ & & $23.32 \pm 4.67$ & \\
\hline Zontrol non-alcoholics $(\mathrm{N}=32)$ & $8.21 \pm 4.31$ & 0.001 & $9.21 \pm 4.12$ & 0.001 & $13.31 \pm 5.08$ & 0.001 \\
\hline
\end{tabular}

MGG: May-Grunwald Giemsa; H \& E: Hematoxylin and Eosin; Pap: Papanicolaou stain; *P value <0.05 was considered statistically significant

\section{Discussion}

Workers of building construction are exposed to various carcinogens such as quartz dust of crystalline silica, diesel fumes asbestos and heavy metals $(5,15)$. Studies performed by Consonni et al. (5) and Tse et al. (16) showed that bricklayer/ construction workers are exposed to increased risk of lung cancer.

We evaluated the genotoxicity in the building construction workers and found higher frequencies of MN compared to the controls, regardless of staining methods used. These findings were considered statistically significant $(\mathrm{P}=0.001)$. Our study revealed that it is possible to analyze the frequencies of $\mathrm{MN}$ in exfoliated buccal epithelial cells using LBC preparations. Similar to our study, Sellappa et al. (6) found that significantly increased frequencies of MN led to more damage to DNA and repair inhibition in building construction workers.

LBC is superior than conventionally prepared exfoliated cytology in certain circumstances viz a) provides clean background by removing almost all mucus, proteins and red blood cells, b) even distribution, improved morphology of cells and nuclear characteristics) cell clusters maintenance, d) effective fixation of samples (17-20).

The first study that applied LBC preparations in exfoliated buccal epithelial cells was performed by Kujan et al. (21) who found a uniform distribution of cells in addition to improved cytomorphology and visibility of nuclear details and thereby offering a superior and unbiased sample while controlling cell density, reducing scanty preparations and eliminating air drying artefacts. A study by Hayama et al. (22) showed improved thickness of smears, distribution of cells and reduced cellular overlapping and blood on LBC preparations. Authors also concluded that LBC led to improved sample preservation, adequacy of specimens, visualization of morphology of cells and reproducibility. Hence, slides prepared by LBC technique provide good quality smears with elimination of confounding factors. Thus, application of LBC in MN assay is one way to refine and improve the assessment of this biomarker.

In the Ramos et al. (4) study, slides were stained with Feulgen/fast green, Giemsa and Pap. Of these, Feulgen/fast green was DNA specific and Giemsa and Pap were DNA non-specific and authors found that frequencies of $\mathrm{MN}$ in construction workers were statistically significant compared to the controls $(\mathrm{P}<0.01)$ regardless of staining method used. However, Giemsa and Pap stains showed greater frequencies of $\mathrm{MN}$ compared to Feulgen/fast green. In the current study, we stained the slides with MGG, H \& E and Pap stain and all these stains were DNA non-specific. The present study demonstrated higher frequencies of $\mathrm{MN}$ in construction workers compared to the controls $(\mathrm{P}=0.001)$ regardless of staining methods used.

Cytogenetic damage can be observed in certain lifestyle factors such as smoking, consumption of alcohol, vitamin deficiencies and supplementation $(7,23)$. Moreover, smoking may increase the frequency of $\mathrm{MN}$ in the exfoliated buccal epithelial cells $(24,25)$. In exfoliated buccal epithelial cells, it is not easy to discriminate consequences of alcohol 
from smoking, because either alcohol or smoking can increase frequencies of MN. However, synergistic effect of smoking and alcohol are more evident than nonsmoker and non-drinker controls $(7,26)$. Our study found that cigarette smoking caused significant number of $\mathrm{MN}$ in both cases and controls. However, alcohol consumption neither in cases nor controls shows statistically significant differences. Intercomparison of mean frequencies of MN between smokers, non-smokers, alcoholics and non-alcoholics of cases and controls using various stains showed significant statistical differences $(P=0.001)$.

Slides prepared using LBC technique in our study were in excellent quality with single layer of cells, adequate cellularity, improved cell morphology and absence of obscuring factors such as microbial colonies, inflammatory cells, mucus, staining deposits and necrotic cores. Hence, this preparation reduces the likelihood of false positive results. Residual sample can be used for advanced procedures like immunocytochemistry. Hence, LBC can be used for MN assay in those occupationally exposed to potentially carcinogenic agents.

\section{Conclusion}

There is an increased risk of cytogenetic damage in building construction workers. Our study revealed that evaluation of MN of exfoliated buccal epithelial cells in building construction workers serves as a minimally invasive biomarker for cytogenetic damage. LBC preparations can be applied in MN assay as it improves the quality of smears and cell morphology, decreases the confounding factors and reduces false positive results.

\section{Conflict of interest}

There was no conflict of interest.

\section{References}

1. Bolognesi C, Knasmueller S, Nersesyan A, Thomas P, Fenech M. The HUMNxl scoring criteria for different cell types and nuclear anomalies in the buccal micronucleus cytome assay - an update and expanded photogallery. Mutat Res 2013;753(2):100-13.
2. Fenech M, Kirsch-Volders M, Natarajan AT, Surralles J, Crott JW, Parry J et al. Molecular mechanisms of micronucleus, nucleoplasmic bridge and nuclear bud formation in mammalian and human cells. Mutagenesis 2011;26(1):125-32.

3. Motgi AA, Chavan MS, Diwan NN, Chowdhery A, Channe PP, Shete MV. Assessment of cytogenic damage in the form of micronuclei in oral epithelial cells in patients using smokeless and smoked form of tobacco and non-tobacco users and its relevance for oral cancer. J Can Res Ther 2014;10(1):165-70.

4. Ramos MA, Cury Fde P, Scapulatempo Neto C, Marques MM, Silveira HC. Micronucleus evaluation of exfoliated buccal epithelial cells using liquid-based cytology preparation. Acta Cytol. 2014;58(6):582-8.

5. Consonni D, De Matteis S, Pesatori AC, Bertazzi PA, Olsson AC, Kromhout H, et al. Lung cancer risk among bricklayers in a pooled analysis of case-control studies. Int $\mathbf{J}$ Cancer. 2015;136(2):360-71.

6. Sellappa S, Prathyumnan S, Balachandar V. DNA damage induction and repair inhibition among building construction workers in south India. Asian Pac J Cancer Prev. 2010;11(4):875-80.

7. Holland N, Bolognesi C, Kirsch-Volders M, Bonassi S, Zeiger E, Knasmueller S, et al. The micronucleus assay in human buccal cells as a tool for biomonitoring DNA damage: the HUMN project perspective on current status and knowledge gaps. Mutat Res. 2008;659(1-2):93-108.

8. Bibbo M, Wilber DC: Comprehensive cytopathology. In: Marluce B, Nasuti JF, editors. Evaluations of the sample in smears and liquidbased preparations. ${ }^{\text {rd }}$ ed. Philadelphia: Saunders; 2008. pp. 65-74.

9. Zeppa P. Liquid-based cytology: a 25-year bridge between and the Pap smear and molecular cytopathology. Acta Cytol. 2014;58(6):519-21.

10. Beerman H, van Dorst EB, KuenenBoumeester V, Hogendoorn PC. Superior performance of liquid-based versus conventional cytology in a population-based cervical cancer 
screening program. Gynecol Oncol. 2009;112 (3):572-6.

11. Norimatsu Y, Yanoh K, Kobayashi TK. The role of liquid-based preparation in the evaluation of endometrial cytology. Acta Cytol. 2013;57(5):423-35.

12. Samanta S, Dey P. Micronucleus and its applications. Diagn Cytopathol. 2012;40(1):84-90.

13. Tolbert PE, Shy CM, Allen JW. Micronuclei and other nuclear anomalies in buccal smears: a field test in snuff users. Am J Epidemiol 1991;134(8):840-50.

14. El-Setouhy M, Loffredo CA, Radwan G, Abdel Rahman R, Mahfouz E, Israel E et al. Genotoxic effects of waterpipe smoking on the buccal mucosa cells. Mutat Res 2008;655(1-2):3640.

15. Driscoll T, Nelson D, Steenland K, Leigh J, Concha-Barrientos M, Fingerhut M. The global burden of disease due to occupational carcinogens. Am J Ind Med 2005;48:419-31.

16. Tse LA, Yu IT, Qiu H, Au JS, Wang XR. Occupational risks and lung cancer burden for Chinese men: a population-based case-referent study. Cancer Causes Control 2012;23(1):121-31.

17. Dwivedi N, Agarwal A, Raj V, Kashyap B, Chandra S. Comparison of centrifuged liquid based cytology method with conventional brush cytology in oral lesions. Eur J Gen Dent 2012;1(3):192-6.

18. Ahmed HG, Edris AM, Mohmed EA, Hussein MO. Value of centrifugated liquid-based cytology by papanicolaou and May-Grünwald in oral epithelial cells. Rare Tumors 2009;1(1):e12.
19. Burd EM. Human papillomavirus and cervicalcancer.Clin Microbiol Rev.2003;16(1):1-17.

20. Yadav N, Hegde V, Nambiar S, Hallikeri K. Efficacy of centrifuged liquid-based cytology over conventional cytology in oral squamous cell carcinoma: a diagnostic augmentation. Int J Sci Stud 2015;2(6):150-54.

21. Kujan O, Desai M, Sargent A, Bailey A, Turner A, Sloan P. Potential applications of oral brush cytology with liquid-based technology: results from a cohort of normal oral mucosa. Oral Oncol 2006;42(8):810-8.

22. Hayama FH, Motta AC, Silva Ade P, Migliari DA. Liquid-based preparations versus conventional cytology: specimen adequacy and diagnostic agreement in oral lesions. Med Oral Patol Oral Cir Bucal 2005;10(2):115-22.

23. Agarwal M, Sunitha JD, Dawar G, Rallan NS. Micronuclei assay of exfoliated oral mucosal cells: A review. Ann Dent Spec. 2014;2:47-50.

24. Sarto F, Finotto S, Giacomelli L, Mazzotti $\mathrm{D}$, Tomanin R, Levis AG. The micronucleus assay in exfoliated cells of the human buccal mucosa. Mutagenesis 1987;2(1):11-17.

25. Piyathilake CJ, Macaluso M, Hine RJ, Vinter DW, Richards EW, Krumdieck CL. Cigarette smoking, intracellular vitamin deficiency, and occurrence of micronuclei in epithelial cells of the buccal mucosa. Cancer Epidemiol Biomarkers Prev 1995;4(7):751-8.

26. Stich HF, Rosin MP. Quantitating the synergistic effect of smoking and alcohol consumption with the micronucleus test on human buccal mucosa cells. Int J Cancer 1983;31(3):305308.

\section{How to Cite This Article}

Arul P, Smitha S, Masilamani S, Akshatha C. Micronucleus Assay in Exfoliated Buccal Epithelial Cells Using Liquid Based Cytology Preparations in Building Construction Workers. Iran J Pathol. 2018; 13(1): 31-38. 